\title{
A case of benign subcutaneous emphysema
}

\author{
Max Alexander Clayton-Smith, ${ }^{1}$ Niroshan Sivathasan ${ }^{2}$
}

'Department of Adult Intensive Care Unit, St Mary's Hospital, London, UK

${ }^{2}$ Emergency Department, Joondalup Health Campus, Joondalup, West Australia, Australia

\section{Correspondence to}

Dr Max Alexander

Clayton-Smith,

maxclaytonsmith@gmail.com

Accepted 23 January 2014

\section{DESCRIPTION}

A 53-year-old man presented to the emergency department with a swollen left forearm 2 days after sustaining a left elbow injury falling off a ladder. There was mild pain at the elbow that had responded well to ibuprofen and there were no symptoms of sensory disturbance distal to the injury. On examination, there was a $4 \mathrm{~cm}^{2}$ abrasion on his elbow with a small, $0.5 \mathrm{~cm}$ long, penetrating wound $1 \mathrm{~cm}$ distal to the olecranon and crepitus on palpation of the skin from his distal bicep to wrist but no associated heat or erythema. He was systemically well, vital signs were normal with a white cell count $<10 \times 10^{9} / \mathrm{L}$ and $\mathrm{C}$ reactive protein $<10 \mathrm{mg} / \mathrm{L}$. Radiographs (figures 1 and 2) showed no fracture but a radiolucent layer beneath the skin of the forearm consistent with subcutaneous emphysema. This was confined to the arm with

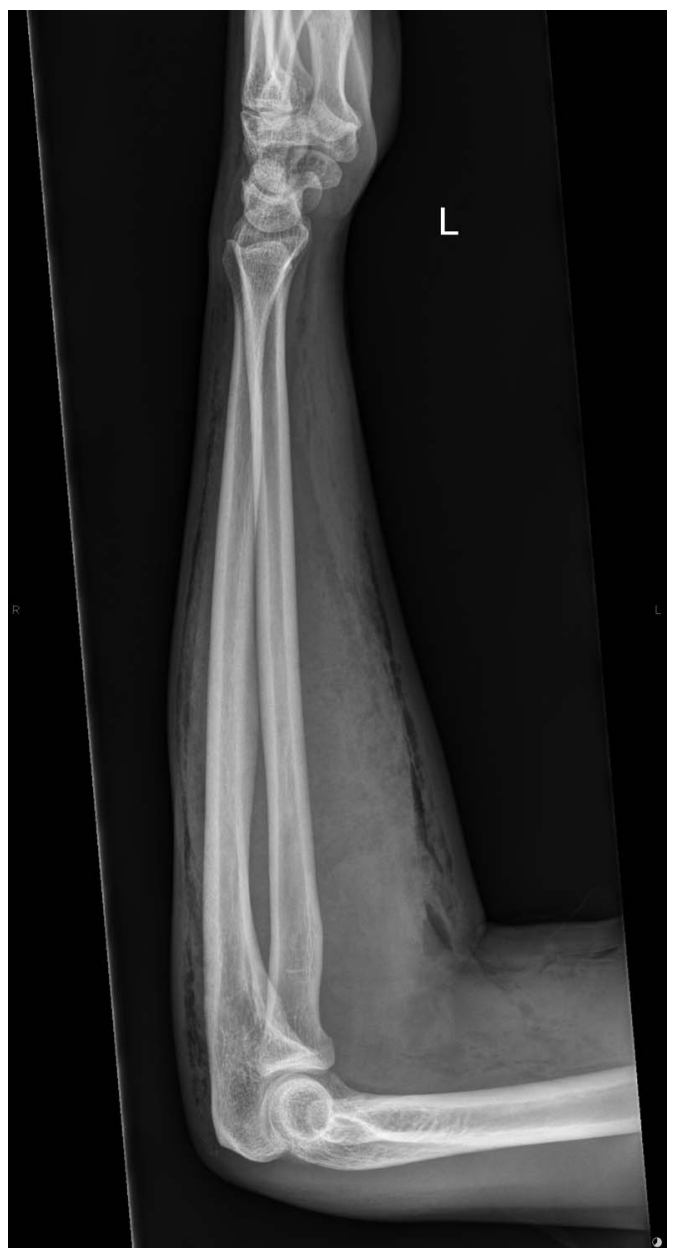

Figure 1 Lateral view of the left forearm demonstrating subcutaneous emphysema extending to the wrist. no extension to the chest wall or signs of pneumothorax. Intramuscular gas was not present, making Clostridial myonecrosis (gas gangrene) unlikely.

Subcutaneous emphysema, defined as gas or air within the subcutaneous tissues, has many causes including following trauma or surgery, pneumothorax, oesophageal rupture, high-pressure injection injury and infection with gas-producing organisms. It is also important to exclude a compartment syndrome (typically associated with an abdominal distribution or high-pressure injection injuries) being caused by the gas. In this case it was considered to have arisen as a result of a valve type mechanism allowing air to enter via the elbow wound. ${ }^{1}$ Discharged on prophylactic antibiotics (cephalexin) to cover potential wound contamination, the patient made a full recovery.

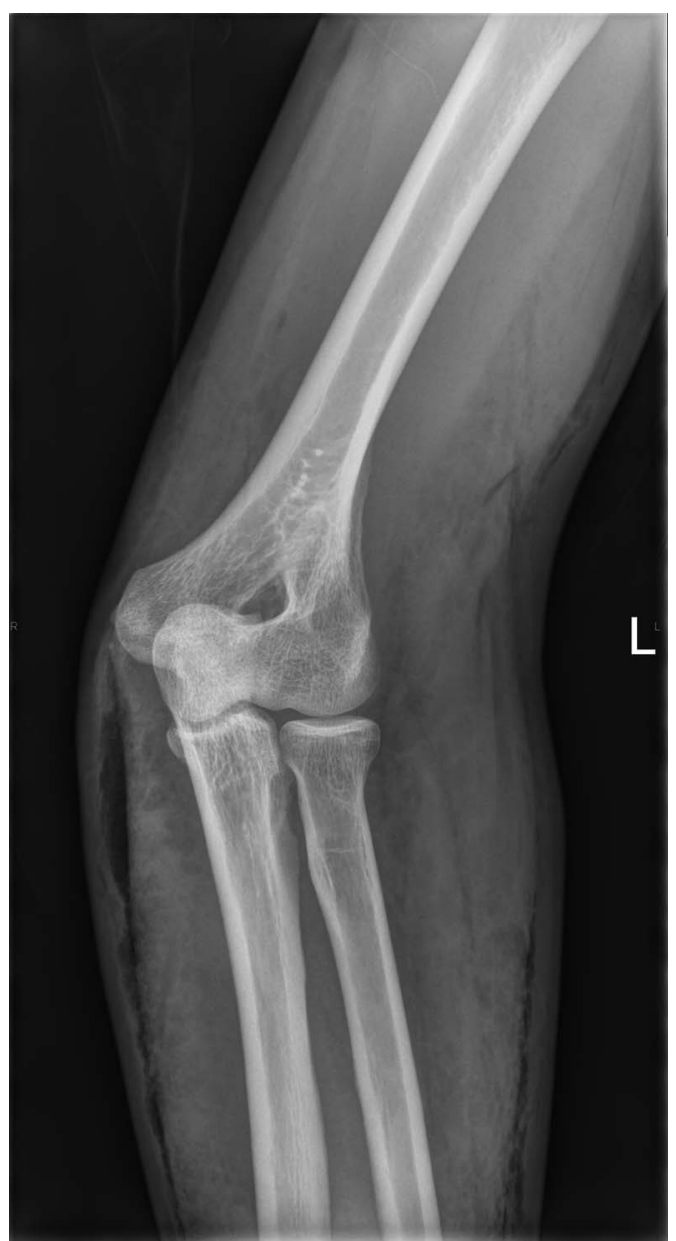

Figure 2 Anteroposterior view of the left elbow and upper arm showing gas confined within the subcutaneous tissue with no evidence of tracking to the chest. 


\section{Learning points}

- Distinguishing between benign subcutaneous emphysema and emphysema secondary to inoculation with Clostridium perfringens or from gas-forming organisms causing necrotising fasciitis is vital to direct management and prevent unnecessary surgical intervention.

- A detailed history enquiring about surgery, trauma, time since injury and systemic symptoms along with measurement of physiological parameters, and blood inflammatory markers help to identify the cause of subcutaneous emphysema.

- Benign subcutaneous emphysema usually resolves spontaneously though severe cases may require surgical decompression.
Contributors MAC reviewed the patient, co-authored the manuscript and is the first author. NS co-authored the manuscript and is the senior author.

Competing interests None.

Patient consent Obtained.

Provenance and peer review Not commissioned; externally peer reviewed.

\section{REFERENCE}

1 Fox A, Sheick H, Ekwobi $C$, et al. Benign surgical emphysema of the hand and upper limb: gas is not always gangrene_-a report of two cases. Emerg Med J 2007; 24:798-9.

Copyright 2014 BMJ Publishing Group. All rights reserved. For permission to reuse any of this content visit http://group.bmj.com/group/rights-licensing/permissions.

BMJ Case Report Fellows may re-use this article for personal use and teaching without any further permission.

Become a Fellow of BMJ Case Reports today and you can:

- Submit as many cases as you like

- Enjoy fast sympathetic peer review and rapid publication of accepted articles

- Access all the published articles

- Re-use any of the published material for personal use and teaching without further permission

For information on Institutional Fellowships contact consortiasales@bmjgroup.com

Visit casereports.bmj.com for more articles like this and to become a Fellow 